The Canadian Mineralogist

Vol. 42, pp. $731-739$ (2004)

\title{
TURANITE, $\mathrm{Cu}^{2+}{ }_{5}\left(\mathrm{~V}^{5+} \mathrm{O}_{4}\right)_{2}(\mathrm{OH})_{4}$, FROM THE TYUYA-MUYUN RADIUM-URANIUM DEPOSIT, OSH DISTRICT, KYRGYZSTAN: A NEW STRUCTURE FOR AN OLD MINERAL
}

\author{
ElENa SOKOLOVA ${ }^{\S}$ AND FRANK C. HAWTHORNE \\ Department of Geological Sciences, University of Manitoba, Winnipeg, Manitoba R3T 2N2, Canada \\ Vladimir V. KARPENKO, Atali A. AGAKHANOV and Leonid A. PAUTOVII \\ Fersman Mineralogical Museum, Russian Academy of Sciences, Leninskii Pr. 18/2, RU-117071 Moscow, Russia
}

AbSTRACT

The crystal structure of turanite, $\mathrm{Cu}^{2+}{ }_{5}\left(\mathrm{~V}^{5+} \mathrm{O}_{4}\right)_{2}(\mathrm{OH})_{4}$, from the Tyuya-Muyun Ra-U deposit, the Alai Ridge foothills, Osh district, Kyrgyzstan, triclinic, space group $P \overline{1}, a$ 5.3834(2), $b$ 6.2736(3), $c$ 6.8454(3) $\AA, \alpha$ 86.169(1), $\beta$ 91.681(1), $\gamma$ 92.425(1) , $V 230.38(2) \AA^{3}, Z=1$, has been solved by direct methods and refined to an $R$ index of $2.2 \%$ based on 1332 observed $\left[F_{\mathrm{o}}>4 \sigma F\right]$ unique reflections measured with $\mathrm{MoK} \alpha \mathrm{X}$-radiation and a Bruker $P 4$ diffractometer equipped with a CCD detector. Chemical analysis by electron microprobe gave $\mathrm{CuO} 62.94, \mathrm{~V}_{2} \mathrm{O}_{5} 28.90, \mathrm{H}_{2} \mathrm{O} 5.85$, sum 97.69 wt. \%; the amount of $\mathrm{H}_{2} \mathrm{O}$ was determined by crystal-structure analysis. The resulting empirical formula on the basis of 12 anions (including $\mathrm{OH}=4 \mathrm{apfu}$ ) is $\mathrm{Cu}^{2+}{ }_{4.97}\left(\mathrm{~V}^{5+} \mathrm{O}_{4}\right)_{2}$ $(\mathrm{OH})_{4.08}$. There are three distinct $\mathrm{Cu}$ sites fully occupied by $\mathrm{Cu}^{2+}$ and octahedrally coordinated by four $\mathrm{O}$ atoms and two $(\mathrm{OH})$ groups, with $\langle C u-\mathrm{O}, \mathrm{OH}\rangle=2.115 \AA$. The $\left(\mathrm{Cu}_{6}\right)$ octahedra $(\phi=\mathrm{O}, \mathrm{OH})$ form a sheet of edge-sharing octahedra (with vacancies, oct : vac $=5: 1)$ parallel to $(011)$. On each side of the vacant octahedron, a $\left(\mathrm{VO}_{4}\right)$ tetrahedron is attached to three anions of the sheet and points away from the sheet to be attached to an anion of the adjacent sheet. Thus the $\left(\mathrm{Cu} \phi_{6}\right)$ octahedra and $\left(\mathrm{VO}_{4}\right)$ tetrahedra constitute a framework, within which the sheets are also linked by hydrogen bonding from $(\mathrm{OH})$ groups of one sheet to $\mathrm{O}$ anions of adjacent sheets. Turanite can be considered as a framework structure with interrupted sheets of $\left(\mathrm{Cu}_{6}\right)$ octahedra decorated by $\left(\mathrm{VO}_{4}\right)$ tetrahedra, and is related to the structures of cornubite, cianciulliite, gordaite, bechererite, chalcophyllite, ramsbeckite and simonkolleite.

Keywords: turanite, crystal structure, Tyuya-Muyun, Osh district, Kyrgyzstan.

\section{SOMMAIRE}

Nous avons résolu la structure cristalline de la turanite, $\mathrm{Cu}^{2+}{ }_{5}\left(\mathrm{~V}^{5+} \mathrm{O}_{4}\right)_{2}(\mathrm{OH})_{4}$, provenant de la localité type, le gisement de Ra-U de Tyuya-Muyun, crêtes d'Alaï, district de Osh, au Kyrgyzstan, triclinique, groupe spatial $P \overline{1}, a$ 5.3834(2), $b$ 6.2736(3), $c$ 6.8454(3) A, $\alpha$ 86.169(1), $\beta$ 91.681(1), $\gamma 92.425(1)^{\circ}, V 230.38(2) \AA^{3}, Z=1$, par méthodes directes, et nous l'avons affiné jusqu'à

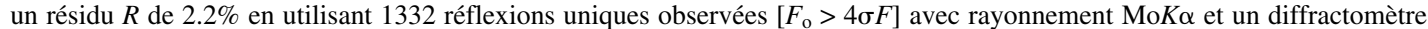
Bruker $P 4$ muni d'un détecteur $\mathrm{CCD}$. Une analyse chimique avec une microsonde électronique a donné $\mathrm{CuO} 62.94, \mathrm{~V}_{2} \mathrm{O}_{5} 28.90$, $\mathrm{H}_{2} \mathrm{O} 5.85$, somme $97.69 \%$ (poids); la teneur en $\mathrm{H}_{2} \mathrm{O}$ a été établie par analyse de la structure. La formule empirique suivante est calculée sur une base de 12 anions (y inclus quatre groupes $\mathrm{OH}$ par unité formulaire): $\mathrm{Cu}^{2+}{ }_{4.97}\left(\mathrm{~V}^{5+} \mathrm{O}_{4}\right)_{2}(\mathrm{OH})_{4.08}$. Il y a trois sites $\mathrm{Cu}$ distincts, qu'occupe le $\mathrm{Cu}^{2+}$ en coordinence octaédrique, entouré de quatre atomes $\mathrm{O}$ et deux groupes $(\mathrm{OH})$, avec $\langle\mathrm{Cu}-\mathrm{O}, \mathrm{OH}\rangle$ $=2.115 \AA$ A Les agencements $\left(\mathrm{Cu}_{6}\right)(\phi: \mathrm{O}, \mathrm{OH})$ forment un feuillet d'octaèdres à arêtes partagées, parallèle à $(011)$, dans lequel le rapport octaèdres à lacunes est $5: 1$. De chaque côté de l'octaèdre vacant, un tétraèdre $\left(\mathrm{VO}_{4}\right)$ se rattache aux trois anions du feuillet et pointe dans la direction opposée, pour ainsi se rattacher au feuillet adjacent. Les octaèdres $\left(\mathrm{Cu} \phi_{6}\right)$ et les tétraèdres $\left(\mathrm{VO}_{4}\right)$ constituent ainsi une trame, dans laquelle les feuillets sont aussi interliés par liaisons hydrogène venant des groupes $\mathrm{OH}$ d'un feuillet, et dirigés vers les anions $\mathrm{O}$ d'un feuillet adjacent. La turanite serait donc une structure en trame ayant des feuillets interrompus d'octaèdres $\left(\mathrm{Cu} \phi_{6}\right)$ décorés par des tétraèdres $\left(\mathrm{VO}_{4}\right)$, avec des points de ressemblance à la structure de la cornubite, la cianciulliite, la gordaïte, la bechererite, la chalcophyllite, la ramsbeckite et la simonkolléite.

Mots-clés: turanite, structure cristalline, Tyuya-Muyun, district de Osh, Kyrgyzstan.

$\S \quad$ E-mail address: elena_sokolova@umanitoba.ca

II E-mail address: pla@fmm.ru 


\section{INTRODUCTION}

Turanite, $\mathrm{Cu}_{5}\left(\mathrm{VO}_{4}\right)_{2}(\mathrm{OH})_{4}$, was described as a new mineral from the Tyuya-Muyun radium-uranium deposit, in the foothills of the Alai range, Osh district, Kyrgyzstan (the former Fergana district) by Nenadkevich (1909). The name turanite is in reference to the locality, which occurs at "the southern frontier of the Turan basin" (Nenadkevich 1909). The mineralogy of the Tyuya-Muyun deposit has been thoroughly investigated by several authors (Alexandrov 1923, Fersman 1928, Suloev \& Ponomarev 1934, Smol'yaninova 1970). Kazansky (1970) summarized the geological and structural characteristics of the Tyuya-Muyun deposit. It occurs in intensely deformed Carboniferous carbonate rocks; the country rocks are synclinally folded with traversing faults. The carbonate rocks show tectonic fissures and disjunctive joints, and the morphology of the orebodies is related to the karst topography. The orebearing marbles, with associated quartz-barite mineralization, contain tyuyamunite, $\mathrm{Ca}\left(\mathrm{U}^{4+} \mathrm{O}_{2}\right)_{2} \mathrm{~V}^{4+}{ }_{2} \mathrm{O}_{8}$ $\left(\mathrm{H}_{2} \mathrm{O}\right)_{5-8}$, tangeite, $\mathrm{Ca} \mathrm{Cu}^{2+}\left(\mathrm{V}^{5+} \mathrm{O}_{4}\right)(\mathrm{OH})$, malachite, $\mathrm{Cu}^{2+}{ }_{2}\left(\mathrm{CO}_{3}\right)(\mathrm{OH})_{2}$, chrysocolla, $\left(\mathrm{Cu}^{2+}, \mathrm{Al}\right)_{2} \mathrm{H}_{2} \mathrm{Si}_{2} \mathrm{O}_{5}$ $(\mathrm{OH})_{4}\left(\mathrm{H}_{2} \mathrm{O}\right)_{\mathrm{n}}$, and turanite. Smol'yaninova (1970) reported two additional vanadates, descloizite, $\mathrm{Pb}^{2+} \mathrm{Zn}$ $\left(\mathrm{VO}_{4}\right)(\mathrm{OH})$, and vanadinite, $\mathrm{Pb}^{2+}{ }_{5}\left(\mathrm{~V}^{5+} \mathrm{O}_{4}\right) \mathrm{Cl}$.

Turanite has long been recognized as an incompletely described mineral species, but it has recently been reported from the Van-Nav-San claim, Gibellini district, Nevada, and the Gold Quarry mine, Maggie Creek district, Nevada (Pullman \& Thomsson 1999,
Castor \& Ferdock 2004). The work presented here confirms turanite as a valid mineral species.

SAMPLE

For the single-crystal X-ray study, we used two grains from specimen MM No. 3578 in the systematic collection of the Fersman Mineralogical Museum, Russian Academy of Sciences, Moscow, Russia. The specimen was taken from the Tyuya-Muyun deposit by K.A. Nenadkevich in 1910 and deposited at the Museum in 1912. Therefore, this material is the holotype specimen. Turanite consists of spherulitic radial aggregates filling a $2 \times 3 \mathrm{~cm}$ cavity in barite (Fig. 1). The mineral is deep olive-green in color, similar to volborthite, and is easily distinguished from malachite and acicular light-green crystals of tangeite $(<0.2 \mathrm{~mm})$ on the surface of the spherulites of turanite, which attain $6 \mathrm{~mm}$ in diameter. Under the optical microscope, all turanite crystals show polysynthetic twinning and a tabular habit. It is difficult to see any habit for turanite crystals in the specimen MM No. 3578 because of a crust of tangeite crystals. However, the tabular habit of turanite is easily seen in the SEM image of a crystal collected recently in the TyuyaMuyun deposit (Fig. 2).

\section{Chemical Analysis}

Chemical analyses (Table 1) were done with a JXA$50 \mathrm{~A}$ electron microprobe operating at $20 \mathrm{kV}$ and $20 \mathrm{nA}$. The following standards and crystals were used for $K$ or

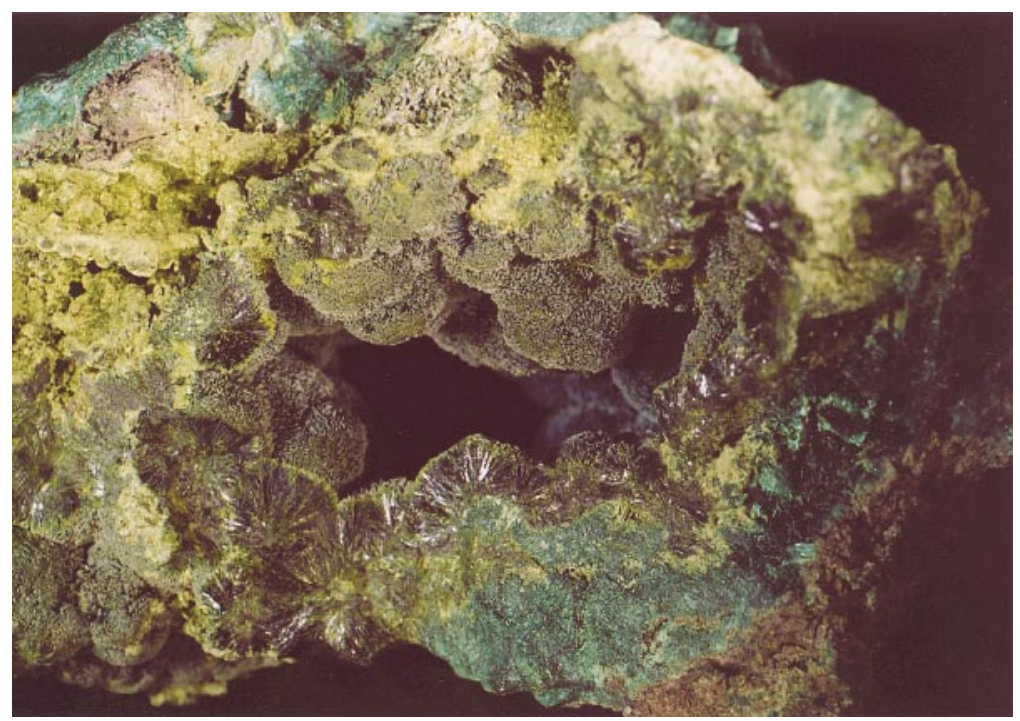

FIG. 1. The holotype specimen of turanite (\#3578) from the collection of the Fersman Mineralogical Museum (Moscow, Russia). Size of sample is $4.5 \times 7.5 \mathrm{~cm}$. Photograph by N.A. Pekova. 
$L$ X-ray lines: $\mathrm{Cu}$ : dioptase $\mathrm{CuSiO}_{2}(\mathrm{OH})_{2} ; \mathrm{V}$ : metallic; $\left(\mathrm{H}_{2} \mathrm{O}\right)$ was calculated from structure solution and refinement. Data were reduced using the $\phi(\rho \mathrm{Z})$ procedure of Pouchou \& Pichoir (1985). The chemical composition of turanite is given in Table 1 and is the mean of four determinations. The unit formula was calculated on the basis of twelve anions, $8 \mathrm{O}$ atoms $+4(\mathrm{OH})$ groups. The empirical formula, $\mathrm{Cu}^{2+}{ }_{4.97}\left(\mathrm{~V}^{5+} \mathrm{O}_{4}\right)_{2.0}(\mathrm{OH})_{4.08}$, is very close to the ideal composition, $\mathrm{Cu}^{2+}{ }_{5}\left(\mathrm{~V}^{5+} \mathrm{O}_{4}\right)_{2}(\mathrm{OH})_{4}$.

\section{X-Ray Data Collection and Structure Solution}

A small crystal measuring $20 \times 50 \times 60 \mu \mathrm{m}$ was cut from a multi-twinned turanite intergrowth, attached to a glass fiber and mounted on a Bruker $P 4$ automated four-circle diffractometer equipped with APEX $4 \mathrm{~K}$ $\mathrm{CCD}$ detector and MoK $\alpha \mathrm{X}$-radiation. The intensities of 9428 reflections with $\overline{7}<h<7, \overline{8}<k<8, \overline{9}<l<9$ were collected to $59.93^{\circ} 2 \theta$ using $45 \mathrm{~s}$ per $0.2^{\circ}$ frame, and an empirical absorption-correction (SADABS, Sheldrick 1998) was applied. The refined unit-cell parameters (Table 2) were obtained from 4578 reflections with $I>10 \sigma I$. The crystal structure of turanite was solved by direct methods and refined to an $R$ index of $2.2 \%$ for 1332 independent observed reflections with the SHELXTL 5.1 system of programs (Sheldrick 1997). Scattering curves for neutral atoms were taken from the International Tables for Crystallography (1992). Site occupancies were refined for three $\mathrm{Cu}$ sites and one $\mathrm{V}$ site to confirm that they are solely occupied by these particular atoms. In the last stages of the refinement, two $\mathrm{H}$ atoms of two $(\mathrm{OH})$ groups were found in the difference-Fourier map and included in the refinement with two types of constraints: (1) the distances $\mathrm{O}$ (donor)-H were softly fixed at $0.98 \AA$, and (2) the isotropic-displacement factor for a $\mathrm{H}$ atom was constrained to be 1.5 times larger than the displacement parameter of the $\mathrm{O}$ atom of the associated $(\mathrm{OH})$ group. Final atom coordinates and displacement parameters are given in Table 3 , selected interatomic distances are listed in Table 4, Table 5 contains hydrogen bonding information, Table 6 gives the bond valences, and Table 7 lists related minerals. Observed and calculated structure-factors may be obtained from The Depository of Unpublished Data, CISTI, National Research Council, Ottawa, Ontario K1A 0S2, Canada.

\begin{tabular}{|c|c|c|c|}
\hline $\mathrm{CuO}$ & 62.94 & $\mathrm{Cu}^{2+}$ & 4.97 \\
\hline $\mathrm{V}_{2} \mathrm{O}_{5}$ & 28.90 & $\mathrm{~V}^{5+}$ & 2.00 \\
\hline $\begin{array}{l}\mathrm{H}_{2} \mathrm{O}_{\text {cals }}^{*} \\
\text { Total }\end{array}$ & $\frac{5.85}{97.69}$ & $\mathrm{H}^{+}$ & 4.08 \\
\hline
\end{tabular}

* calculated from structure refinement
Description of the Structure

\section{Coordination of the cations}

There are three unique $C u$ sites in turanite, each octahedrally coordinated and fully occupied by $\mathrm{Cu}$ (Figs. 3a, b). The $\mathrm{Cu}(1)$ site is coordinated by four $(\mathrm{OH})$ groups and two $\mathrm{O}$ atoms, with $\mathrm{a}<\mathrm{Cu}-(\mathrm{OH}), \mathrm{O}>$ distance of $2.114 \AA$. The $C u(2)$ and $C u(3)$ sites are each coordinated by four $\mathrm{O}$ atoms and two $(\mathrm{OH})$ groups, with a
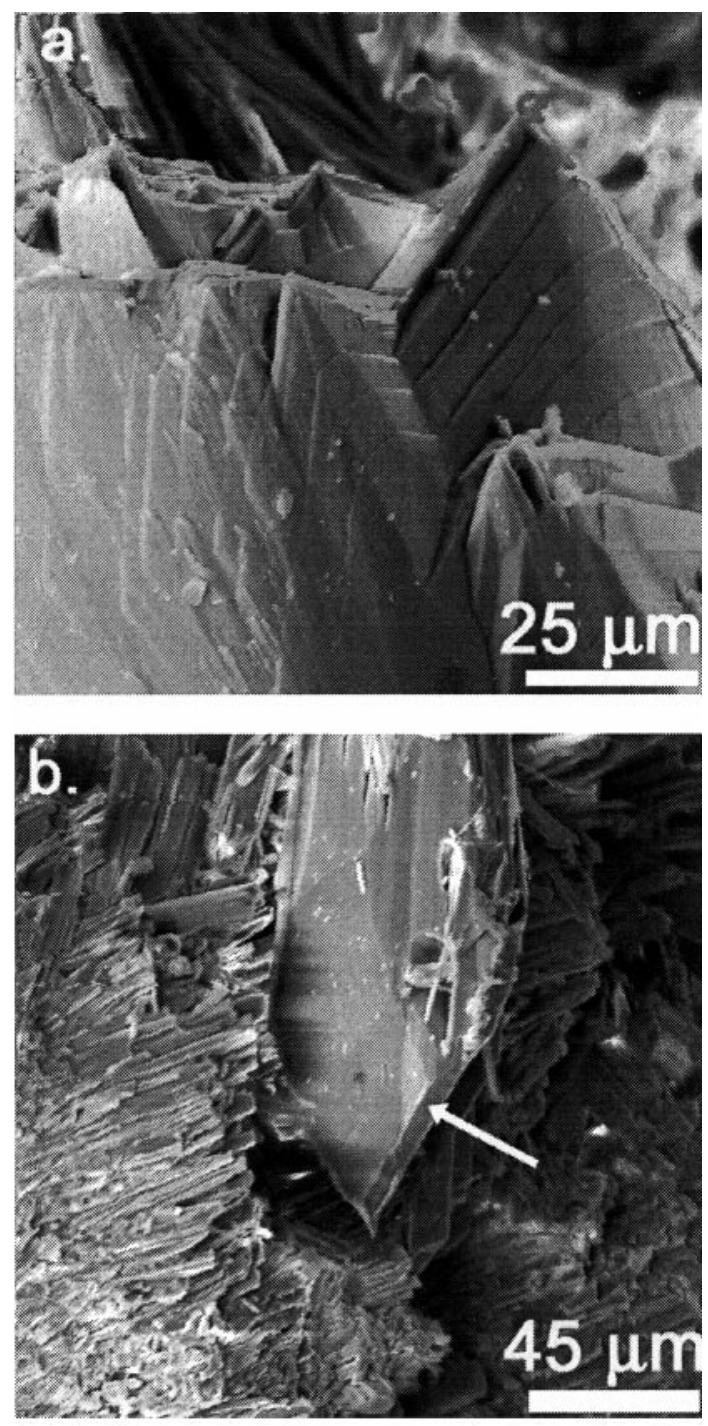

FIG. 2. SEM image of turanite crystals: (a) parallel intergrown crystals; (b) a tabular crystal (shown by arrow) among small crystals of tangeite. 
$<C u(2,3)-\mathrm{O},(\mathrm{OH})>$ distance of $2.116 \AA$. Each $\left(\mathrm{Cu}^{2+} \phi_{6}\right)$ octahedron has four short equatorial bonds and two long apical bonds (Fig. 3b, Table 4), in accord with Burns \& Hawthorne $(1995,1996)$, who showed that octahedrally coordinated $\mathrm{Cu}^{2+}$ is characterized by elongation (rather than shortening) of apical bonds. The directions of elon-

\begin{tabular}{|c|c|}
\hline$a(\AA)$ & $5.3834(2)$ \\
\hline$b$ & $6.2736(3)$ \\
\hline$c$ & $6.8454(3)$ \\
\hline$\alpha\left({ }^{\circ}\right)$ & $86.169(1)$ \\
\hline$\beta$ & $91.681(1)$ \\
\hline Y & $92.425(1)$ \\
\hline$V\left(\AA^{3}\right)$ & $230.38(2)$ \\
\hline Space group & $P \overline{1}$ \\
\hline$z$ & 1 \\
\hline $\begin{array}{l}\text { Absorption coefficient } \\
\left(\mathrm{mm}^{-1}\right)\end{array}$ & 13.38 \\
\hline$F(000)$ & 323.0 \\
\hline$D_{\text {calc }}\left(\mathrm{g} / \mathrm{cm}^{3}\right)$ & 4.898 \\
\hline Crystal size (mm) & $0.02 \times 0.05 \times 0.06$ \\
\hline Radiation/ filter & MoKa/graphite \\
\hline $\begin{array}{l}2 \theta \text {-range for data } \\
\text { collection }\left({ }^{\circ}\right)\end{array}$ & 59.93 \\
\hline$R($ int $)(\%)$ & 0.8 \\
\hline $\begin{array}{l}\text { Reflections collected } \\
F_{0}>4 \sigma|F|\end{array}$ & $\begin{array}{l}6381 \\
2686\end{array}$ \\
\hline $\begin{array}{l}\text { Independent reflections } \\
F_{0}>4 \sigma|F|\end{array}$ & $\begin{array}{l}1346 \\
1332\end{array}$ \\
\hline Refinement method & $\begin{array}{l}\text { Full-matrix least-squares on } F^{2} \\
\text { fixed weights proportional to } 1 / \sigma F_{0}^{2}\end{array}$ \\
\hline Goodness of fit on $F^{2}$ & 1.192 \\
\hline $\begin{array}{l}\text { Final } R(o b s)(\%) \\
{\left[F_{0}>4 \sigma|F|\right]}\end{array}$ & $R_{1}=2.2$ \\
\hline$R$ indices (all data) (\%) & $\begin{array}{l}R_{1}=2.2 \\
W R_{2}=5.7 \\
\text { GoF }=1.192\end{array}$ \\
\hline
\end{tabular}

gation for the $C u(1)$ and $C u(2)$ octahedra are orthogonal to [01 $\overline{1}$, whereas for the $C u(3)$ octahedron, it is oblique to [011] ]. This is a result of the bond-valence requirements of the coordinating $\mathrm{O}$ atoms and $(\mathrm{OH})$ groups and the connectivity of polyhedra in the structure. The $C u(1)$ and $C u(2)$ octahedra share common edges to form a chain along [01 1$]$ with a repeat sequence $[C u(1)=C u(2)=C u(2)]$. Two $C u(3)$ octahedra share a common edge and alternate with a vacant octahedron along [011] (Figs. 3a, b). The size of the vacant octahedron is smaller than that of the $\mathrm{Cu}$ octahedra as the former links to two $V$ tetrahedra, above and below the sheet, which constrains the size of the vacant octahedron. The repeat distances of the two chains $[C u(1)=$ $C u(2)=C u(2)]$ and $[C u(3)=C u(3)=\square]$ (Fig. 3a) must be equal. As the vacant octahedron is smaller than the $C u$ octahedra, the $[C u(3)=C u(3)=\square]$ chain must increase its length relative to that of a chain of holosymmetric octahedra of similar size, whereas the $[\mathrm{Cu}(1)$ $=C u(2)=C u(2)]$ chain must decrease its length relative to that of a chain of holosymmetric octahedra of similar size. These changes occur via the orientation of the Jahn-Teller elongation of the occupied octahedra: $C u(1)$ and $C u(2)$ octahedra elongate orthogonal to [01 1 , thereby shortening the $[C u(1)=C u(2)=C u(2)]$ chain in this direction, whereas the $\mathrm{Cu}(3)$ octahedron elongates at an oblique angle to [01], and hence the $[C u(3)=C u(3)$ $=\square$ ] chain is extended by the component of octahedron elongation parallel to [01 $\overline{1}$ ].

There is one unique $V$ site tetrahedrally coordinated by $\mathrm{O}$ atoms, with a $<\mathrm{V}-\mathrm{O}>$ distance of $1.725 \AA$. The $V$ tetrahedron has one short bond $V-\mathrm{O}(4)=1.660 \AA$. In order to satisfy its bond-valence requirements, the $\mathrm{O}(4)$ atom has two long bonds with $C u(2)$ and $C u(3)$.

\section{Structure topology}

The $C u(1), C u(2)$ and $C u(3)$ octahedra share six, three and five edges with adjacent octahedra to form an

TABLE 3. FINAL ATOM POSITIONS AND DISPLACEMENT PARAMETERS ( $\left.\AA^{2}\right)$ FOR TURANITE

\begin{tabular}{|c|c|c|c|c|c|c|c|c|c|c|}
\hline & $x$ & $y$ & $z$ & $U_{\mathrm{eq}}$ & $U_{11}$ & $U_{22}$ & $U_{33}$ & $U_{23}$ & $U_{13}$ & $U_{12}$ \\
\hline $\mathrm{Cu}(1)$ & 0 & $1 / 2$ & 0 & $0.00884(10)$ & $0.00821(18)$ & $0.00867(19)$ & $0.00937(19)$ & $0.00302(13)$ & $0.00157(13)$ & $0.00188(13)$ \\
\hline $\mathrm{Cu}(2)$ & $-0.00879(5)$ & $0.15238(4)$ & $0.33553(4)$ & $0.00897(9)$ & $0.01027(15)$ & $0.00822(15)$ & $0.00849(15)$ & $0.00202(10)$ & $0.00262(10)$ & $0.00342(10)$ \\
\hline $\mathrm{Cu}(3)$ & $-0.50426(5)$ & $0.32074(4)$ & $0.17404(4)$ & $0.00894(10)$ & $0.00786(15)$ & $0.00699(15)$ & $0.01183(16)$ & $0.00012(10)$ & $-0.00061(10)$ & $0.00053(10)$ \\
\hline$v$ & $-0.56313(7)$ & $0.80958(6)$ & $0.31396(5)$ & $0.00732(10)$ & $0.00783(17)$ & $0.00639(17)$ & $0.00786(17)$ & $-0.00081(12)$ & $0.00104(12)$ & $0.00050(12)$ \\
\hline$O(1)$ & $0.1473(3)$ & $-0.1188(3)$ & $0.4007(3)$ & $0.0104(3)$ & $0.0106(7)$ & $0.0099(7)$ & $0.0108(7)$ & $0.0014(6)$ & $0.0039(6)$ & $0.0030(6)$ \\
\hline$O(2)$ & $-0.6197(3)$ & $0.6156(3)$ & $0.1464(3)$ & $0.0101(3)$ & $0.0115(7)$ & $0.0077(7)$ & $0.0114(7)$ & $-0.0019(6)$ & $-0.0002(6)$ & $0.0016(6)$ \\
\hline$O(3)$ & $-0.6049(3)$ & $-0.0228(3)$ & $-0.2017(3)$ & $0.0106(3)$ & $0.0117(7)$ & $0.0081(7)$ & $0.0120(7)$ & $0.0002(6)$ & $0.0013(6)$ & $0.0007(6)$ \\
\hline$O(4)$ & $-0.3827(3)$ & $0.7093(3)$ & $0.4952(3)$ & $0.0120(3)$ & $0.0148(8)$ & $0.0107(8)$ & $0.0102(7)$ & $-0.0002(6)$ & $-0.0009(6)$ & $0.0004(6)$ \\
\hline$O(5)$ & $0.1586(3)$ & $0.2236(3)$ & $0.0820(3)$ & $0.0100(3)$ & $0.0097(7)$ & $0.0108(8)$ & $0.0096(7)$ & $-0.0000(6)$ & $0.0012(6)$ & $0.0016(6)$ \\
\hline$O(6)$ & $-0.1633(3)$ & $0.4229(3)$ & $0.2514(2)$ & $0.0086(3)$ & $0.0088(7)$ & $0.0085(7)$ & $0.0087(7)$ & $-0.0006(5)$ & $0.0006(5)$ & $0.0003(6)$ \\
\hline$H(1)$ & $0.193(8)$ & $0.119(5)$ & $-0.012(5)$ & $0.043(12)^{\star}$ & & & & & & \\
\hline$H(2)$ & $-0.185(6)$ & $0.529(4)$ & $0.346(4)$ & $0.01037(10)^{*}$ & & & & & & \\
\hline
\end{tabular}

${ }^{*} \mathrm{U}_{\text {iso }}$ 
interrupted sheet of octahedra (Fig. 3a). In this sheet, each vacant octahedron is surrounded by four $\mathrm{Cu}(2)$ octahedra and two $\mathrm{Cu}(3)$ octahedra, and is sandwiched between two $V$ tetrahedra with their apices pointing away from the sheet (Fig. 4a). These sheets form a framework (Fig. 4b).

\section{Hydrogen bonding}

The bond-valence incident at the various anions from the $C u$ cations (Table 6) show $\mathrm{O}(5)$ and $\mathrm{O}(6)$ to be $(\mathrm{OH})$

\begin{tabular}{|c|c|c|c|c|}
\hline $\mathrm{Cu}(1)-\mathrm{O}(2)$ & $\times 2$ & $2.360(2)$ & $V-O(1)$ & $1.770(2)$ \\
\hline $\mathrm{Cu}(1)-\mathrm{O}(5)$ & $\times 2$ & $2.004(2)$ & $V-O(2)$ & $1.739(2)$ \\
\hline $\mathrm{Cu}(1)-\mathrm{O}(6)$ & $x 2$ & $1.977(2)$ & $V-O(3)$ & $1.731(2)$ \\
\hline \multirow[t]{2}{*}{$<\mathrm{Cu}(1)-\mathrm{O}\rangle$} & & 2.114 & $V-O(4)$ & $1.660(2)$ \\
\hline & & & $\langle V-O\rangle$ & 1.725 \\
\hline $\mathrm{Cu}(2)-\mathrm{O}(1)$ & & $1.948(2)$ & $\mathrm{Cu}(3)-\mathrm{O}(2)$ & $1.971(2)$ \\
\hline $\mathrm{Cu}(2)-\mathrm{O}(1) \mathrm{a}$ & & $1.969(2)$ & $\mathrm{Cu}(3)-\mathrm{O}(2) \mathrm{b}$ & $2.316(2)$ \\
\hline $\mathrm{Cu}(2)-\mathrm{O}(3)$ & & $2.381(2)$ & $\mathrm{Cu}(3)-\mathrm{O}(3)$ & $1.979(2)$ \\
\hline $\mathrm{Cu}(2)-\mathrm{O}(4)$ & & $2.525(2)$ & $C u(3)-O(4)$ & $2.355(2)$ \\
\hline $\mathrm{Cu}(2)-\mathrm{O}(5)$ & & $1.994(2)$ & $\mathrm{Cu}(3)-\mathrm{O}(5)$ & $1.989(2)$ \\
\hline $\mathrm{Cu}(2)-\mathrm{O}(6)$ & & $1.966(2)$ & $\mathrm{Cu}(3)-\mathrm{O}(6)$ & $1.987(2)$ \\
\hline$\langle\mathrm{Cu}(2)-\mathrm{O}\rangle$ & & 2.131 & $\langle\mathrm{Cu}(3)-\mathrm{O}\rangle$ & 2.100 \\
\hline
\end{tabular}

TABLE 5. HYDROGEN BONDING IN TURANITE

\begin{tabular}{|c|c|c|c|c|c|}
\hline $\mathrm{D}-\mathrm{H} \ldots \mathrm{A}$ & $\mathrm{D}-\mathrm{H}(\mathrm{A})$ & $\mathrm{H} \ldots \mathrm{A}(\AA)$ & D...A $(\AA)$ & $\angle(\mathrm{DHA})\left({ }^{\circ}\right)$ & $D-A(\AA)$ \\
\hline $\mathrm{O}(5)-\mathrm{H}(1) \ldots \mathrm{O}(3)$ & $0.98(10)$ & $1.99(2)$ & $2.915(3)$ & $156(4)$ & $2.915(3)$ \\
\hline$O(6)-H(2) \ldots O(4)$ & $0.97(10)$ & $1.94(2)$ & $2.847(2)$ & $153(3)$ & $2.847(2)$ \\
\hline
\end{tabular}

groups. The $\mathrm{H}$ atoms associated with the $(\mathrm{OH})$ groups were located in the refinement (Table 3), and Table 5 show the hydrogen-bond arrangements. The $\mathrm{H}(1)$ and $\mathrm{H}(2)$ atoms are hydrogen-bonded to the $\mathrm{O}(3)$ and $\mathrm{O}(4)$ atoms of the adjacent layer (Fig. 5), with an H...O distance of 1.99 and $1.94 \AA$, respectively.

\section{Related Structures}

Hawthorne \& Schindler (2000) examined the principles involved in the structures of hydroxy-hydrated copper (and zinc) minerals based on decorated $\left[\mathrm{Cu}^{2+} \phi_{2}\right]_{N}$ sheets $(\phi$ : any anion of the sheet). Hawthorne $\&$ Sokolova (2002) refined the crystal structure of simonkolleite, $\mathrm{Zn}_{5}(\mathrm{OH})_{8} \mathrm{Cl}_{2}\left(\mathrm{H}_{2} \mathrm{O}\right)$, and considered its structure and some other structures in which there are vacancies at some of the octahedrally coordinated sites

TABLE 6. BOND-VALENCE* $(v u)$ TABLE FOR TURANITE

\begin{tabular}{lllllllc}
\hline & $\mathrm{Cu}(1)$ & $\mathrm{Cu}(2)$ & $\mathrm{Cu}(3)$ & $V$ & $\mathrm{H}(1)$ & $\mathrm{H}(2)$ & $\Sigma$ \\
\hline $\mathrm{O}(1)$ & & 0.471 & & 1.062 & & & 1.974 \\
& & 0.441 & & & & & \\
$\mathrm{O}(2)$ & $0.149^{\times 2}{ }_{1}$ & & 0.439 & 1.162 & & & 1.917 \\
& & & 0.167 & & & & \\
$\mathrm{O}(3)$ & & 0.141 & 0.428 & 1.190 & 0.13 & & 1.889 \\
$\mathrm{O}(4)$ & & 0.099 & 0.151 & 1.473 & & 0.14 & 1.863 \\
$\mathrm{O}(5)$ & $0.397^{\times 2} \downarrow$ & 0.409 & 0.415 & & 0.87 & & 2.091 \\
$\mathrm{O}(6)$ & $0.431^{\times 2} \downarrow$ & 0.445 & 0.418 & & & 0.86 & 2.154 \\
\hline Total & 1.954 & 2.006 & 2.018 & 4.887 & 1.00 & 1.00 & \\
\hline
\end{tabular}

* bond-valence parameters from Brown (1981)

TABLE 7. MINERALS BASED ON CLOSE-PACKED DECORATED $\left[M^{2+} \phi_{2}\right]_{N}$ SHEETS, $\left(M=\mathrm{Cu}^{2+}, \mathrm{Zn}\right)$

\begin{tabular}{|c|c|c|c|c|c|c|c|}
\hline Mineral & Formula & $\begin{array}{l}a(\AA) \\
\alpha\left(^{\circ}\right)\end{array}$ & $\begin{array}{l}b(\AA) \\
\beta\left({ }^{\circ}\right)\end{array}$ & $\begin{array}{l}c(\AA) \\
Y\left({ }^{\circ}\right)\end{array}$ & $\begin{array}{l}\text { Space } \\
\text { group }\end{array}$ & Structure & Ref. \\
\hline Turanite & {$\left[\mathrm{Cu}_{5}\left(\mathrm{VO}_{4}\right)_{2}(\mathrm{OH})_{4}\right]$} & $\begin{array}{l}5.3834(2) \\
86.169(1)\end{array}$ & $\begin{array}{c}6.2736(3) \\
91.681(1)\end{array}$ & $\begin{array}{c}6.8454(3) \\
92.425(1)\end{array}$ & $P^{\top}$ & Framework & (1) \\
\hline Cornubite & {$\left[\mathrm{Cu}_{5}\left(\mathrm{AsO}_{4}\right)_{2}(\mathrm{OH})_{4}\right]$} & $\begin{array}{l}6.121(1) \\
92.93(1)\end{array}$ & $\begin{aligned} 6.251(1) \\
111.30(1)\end{aligned}$ & $\begin{array}{r}6.790(1) \\
107.47(1)\end{array}$ & $P \top$ & Framework & (2) \\
\hline Simonkolleite & {$\left[\mathrm{Zn}_{5}(\mathrm{OH})_{8} \mathrm{Cl}_{2}\right]\left(\mathrm{H}_{2} \mathrm{O}\right)$} & $\begin{array}{c}6.3412(3) \\
-\end{array}$ & $\begin{array}{l}a \\
-\end{array}$ & $\begin{array}{c}23.646(1) \\
-\end{array}$ & $R 3 \mathrm{~m}$ & Sheet & (3) \\
\hline Cianciulliite & $\mathrm{Mn}(\mathrm{Mg}, \mathrm{Mn})_{2} \mathrm{Zn}_{2}(\mathrm{OH})_{12}\left(\mathrm{H}_{2} \mathrm{O}\right)_{2-4}$ & $\begin{array}{c}15.405(3) \\
-\end{array}$ & $\begin{array}{c}6.344(1) \\
101.23(2)\end{array}$ & $\begin{array}{c}5.562(2) \\
-\end{array}$ & $\mathrm{C} 2 / m$ & Sheet & (4) \\
\hline Gordaite & $\mathrm{Na}\left[\mathrm{Zn}_{4}\left(\mathrm{SO}_{4}\right)(\mathrm{OH})_{6} \mathrm{Cl}\right]\left(\mathrm{H}_{2} \mathrm{O}\right)_{6}$ & $\begin{array}{c}8.3556(3) \\
-\end{array}$ & $\begin{array}{l}a \\
-\end{array}$ & $\begin{array}{c}13.025(1) \\
-\end{array}$ & $P 3$ & Sheet & (5) \\
\hline Bechererite & {$\left[\mathrm{Zn}_{7} \mathrm{Cu}^{2+} \mathrm{SiO}(\mathrm{OH})_{3}\left(\mathrm{SO}_{4}\right)(\mathrm{OH})_{13}\right]$} & $\begin{array}{c}8.319(2) \\
-\end{array}$ & a & $\begin{array}{c}7.377(1) \\
-\end{array}$ & $P \overline{3}$ & Framework & (6) \\
\hline Ramsbeckite & $\left(\mathrm{Cu}^{2+}, \mathrm{Zn}\right)_{15}(\mathrm{OH})_{22}\left(\mathrm{SO}_{4}\right)_{4}\left(\mathrm{H}_{2} \mathrm{O}\right)_{6}$ & $\begin{array}{c}16.088(4) \\
-\end{array}$ & $\begin{array}{l}15.576(4) \\
90.22(2)\end{array}$ & $\begin{array}{c}7.102(2) \\
-\end{array}$ & $P 2_{1} / a$ & Framework & (7) \\
\hline
\end{tabular}

References: (1) This work; (2) Sieber et al. (1984); (3) Hawthorne \& Sokolova (2002); (4) Grice \& Dunn (1991); (5) Adiwidjaja et al. (1997); (6) Hoffmann et al. (1997); (7) Effenberger (1988) 
in the sheet, the "interrupted" sheets. For simonkolleite, cianciulliite, $\mathrm{Mn}(\mathrm{Mg}, \mathrm{Mn})_{2} \mathrm{Zn}_{2}(\mathrm{OH})_{10}\left(\mathrm{H}_{2} \mathrm{O}\right)_{2-4}$, gordaite, $\mathrm{Na}\left[\mathrm{Zn}_{4}\left(\mathrm{SO}_{4}\right)(\mathrm{OH})_{6} \mathrm{Cl}\right]\left(\mathrm{H}_{2} \mathrm{O}\right)_{6}$, namuwite, $\left(\mathrm{Zn}, \mathrm{Cu}^{2+}\right)_{4}\left(\mathrm{SO}_{4}\right)(\mathrm{OH})_{6}\left(\mathrm{H}_{2} \mathrm{O}\right)_{4}$, bechererite, $\mathrm{Zn}_{7} \mathrm{Cu}^{2+}$ $\mathrm{Si} \mathrm{O}(\mathrm{OH})_{3}\left(\mathrm{SO}_{4}\right)(\mathrm{OH})_{13}$, chalcophyllite, $\left[\mathrm{Cu}^{2+}{ }_{9} \mathrm{Al}\right.$ $\left.\left(\mathrm{AsO}_{4}\right)_{2}(\mathrm{OH})_{12}\left(\mathrm{H}_{2} \mathrm{O}\right)_{6}\right]\left(\mathrm{SO}_{4}\right)_{1.5}\left(\mathrm{H}_{2} \mathrm{O}\right)_{12}$, ramsbeckite, $\left(\mathrm{Cu}^{2+}{ }_{13}, \mathrm{Zn}_{2}\right)(\mathrm{OH})_{22}\left(\mathrm{SO}_{4}\right)_{4}\left(\mathrm{H}_{2} \mathrm{O}\right)_{6}$, chalcophanite, $\mathrm{Zn}$ $\mathrm{Mn}_{3} \mathrm{O}_{7}\left(\mathrm{H}_{2} \mathrm{O}\right)_{3}$, and claringbullite, $\mathrm{Cu}^{2+}{ }_{4} \mathrm{Cl}(\mathrm{OH})_{6}$ $\left(\mathrm{Cl}_{0.29}(\mathrm{OH})_{0.71}\right)$, they rewrote the formulae by incorporating octahedrally coordinated vacancies and by identifying the decorating oxyanions and their mode of attachment to the sheet, and showed that all these structures have a decorated $\left({ }^{[6]} M \phi_{2}\right)_{N}$ sheet as the structural unit.

The structure of turanite fits into this scheme if we write the formula in the following way: $\left[{ }^{[6]}\left(\mathrm{Cu}^{2+}{ }_{3} \square\right)\right.$ ${ }^{[4]}\left[\mathrm{V}^{5+} \mathrm{O}_{4}\right]_{2}(\mathrm{OH})_{4}$. Each tetrahedron links to three anions of one sheet (Fig. 4a), and hence we can write the $\left(\mathrm{VO}_{4}\right)$ tetrahedra as $\phi_{3}(\phi=$ any anion of the sheet $)$. Hence the above formula reduces to $\left[\left(\mathrm{Cu}_{3} \square\right) \phi_{6+2}\right]=$

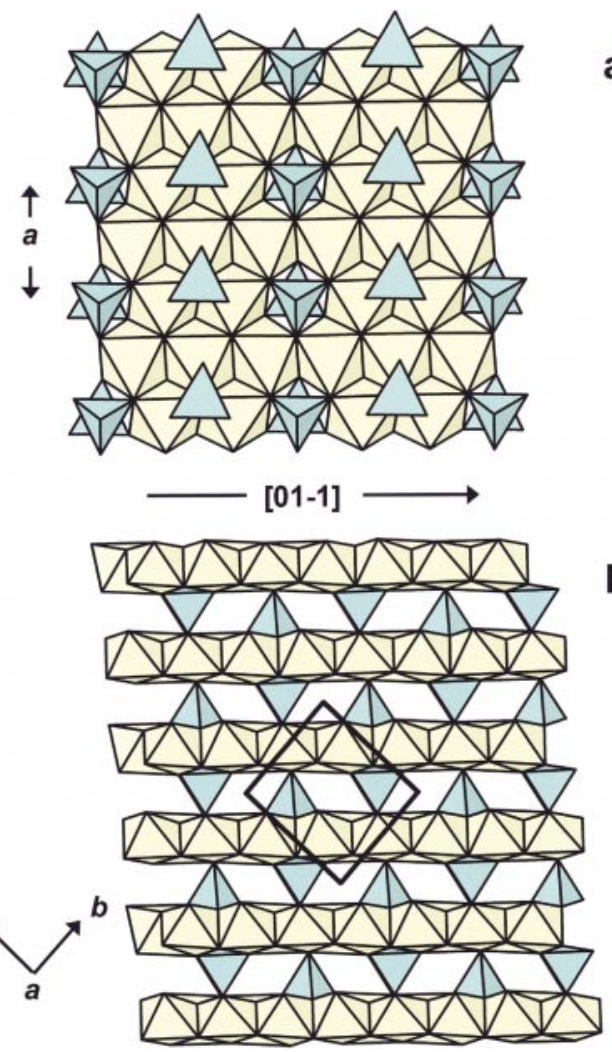

a)

b)

FIG. 4. The crystal structure of turanite: (a) the sheet of $\mathrm{Cu}$ octahedra and V tetrahedra viewed down [011]; (b) the mixed octahedron-tetrahedron framework viewed down [100]; $\mathrm{Cu}$ octahedra are yellow, $\mathrm{V}$ tetrahedra are green.
$\left[M_{4} \phi_{8}\right]=\left[M \phi_{2}\right]_{4}$, where $M={ }^{[6]}(\mathrm{Cu}, \square)$ and $\phi$ represents octahedron ligands. Thus turanite has a structure based on a decorated $\left({ }^{[6]} M \phi_{2}\right)_{N}$ sheet.

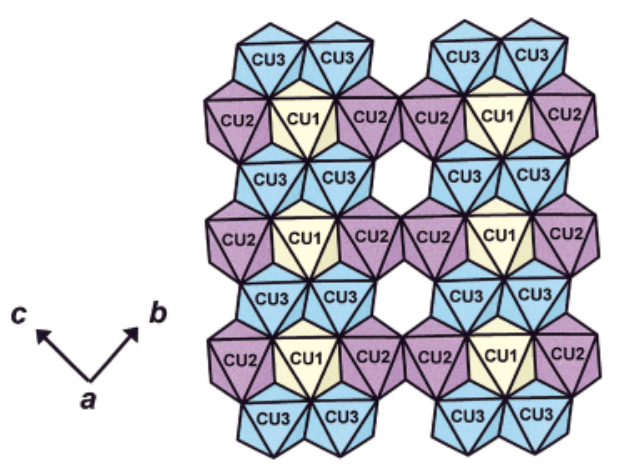

a)

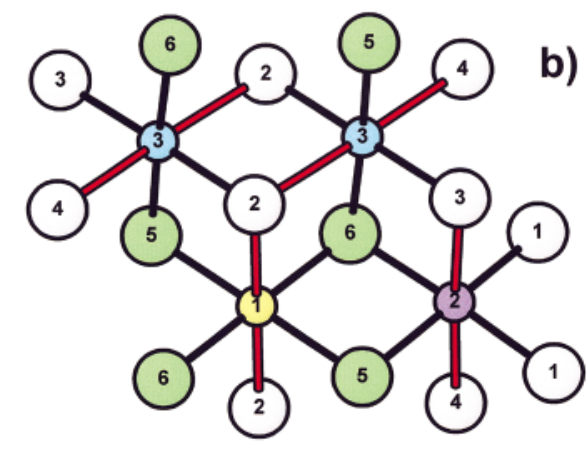

FIG. 3. The crystal structure of turanite: (a) the sheet of $\mathrm{Cu}$ octahedra viewed down [100]; (b) coordination of $\mathrm{Cu}$ sites viewed down [100]; $\mathrm{Cu}(1), \mathrm{Cu}(2)$ and $\mathrm{Cu}(3)$ atoms and octahedra are yellow, mauve and blue; $\mathrm{O}$ atoms are white, $\mathrm{O}$ atoms of $(\mathrm{OH})$ groups are green, $\mathrm{Cu}-\phi$ short and long bonds are black and red, respectively.

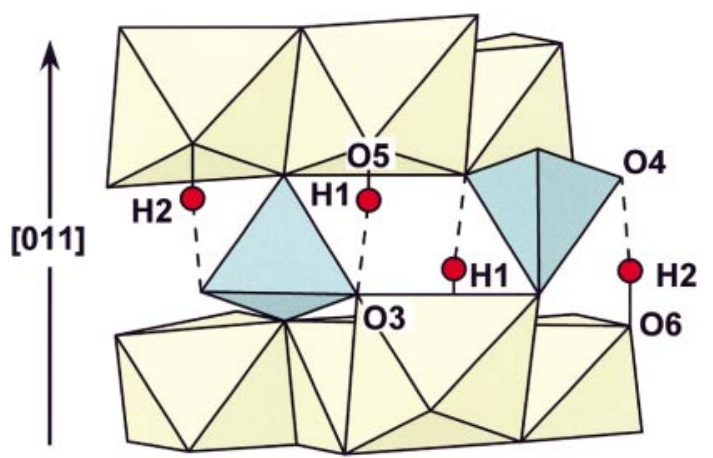

FIG. 5. The hydrogen-bond arrangement in turanite. Legend as in Figure 4; $\mathrm{H}$ atoms are red circles, hydrogen bonds are dashed lines. 
We will consider crystal structures of simonkolleite, cianciulliite and gordaite (Table 7), with the same type of close-packed decorated $\left({ }^{[6]} M \phi_{2}\right)_{N}$ sheets, and cornubite, bechererite and ramsbeckite, in which the particular sheets are part of a framework.

\section{Simonkolleite}

The $\left(\mathrm{Zn} \phi_{6}\right)$ octahedra $(\phi: \mathrm{O}, \mathrm{OH}, \mathrm{Cl})$ form a dioctahedral sheet of edge-sharing octahedra similar to that observed in dioctahedral micas. On each side of the vacant octahedron, a $\left(\mathrm{Zn} \phi_{4}\right)$ tetrahedron is attached to three anions of the sheet and points away from the sheet (Fig. 6a). The decorated sheet can be written as $\left[M_{3} \square\right.$ $\left.\left(T \phi_{4}\right)_{2} \phi_{2}\right]$ where $M={ }^{[6]} \mathrm{Zn}, T={ }^{[4]} \mathrm{Zn}$ and $\phi=\mathrm{OH}, \mathrm{Cl}$. The sheets are held together by hydrogen bonding from $(\mathrm{OH})$ groups of one sheet to $\mathrm{Cl}$ anions of adjacent sheets, and to interstitial $\left(\mathrm{H}_{2} \mathrm{O}\right)$ groups.

\section{Cianciiullite}

Cianciulliite has an interrupted sheet of the form $\left[M \phi_{2}\right]_{4}$, where $M=\mathrm{Mn}^{2+}$, and $\left(\mathrm{Mg}_{0.5} \mathrm{Mn}^{2+}{ }_{0.5}\right)$ and $\square$ (Hawthorne \& Sokolova 2002). Each vacancy in the

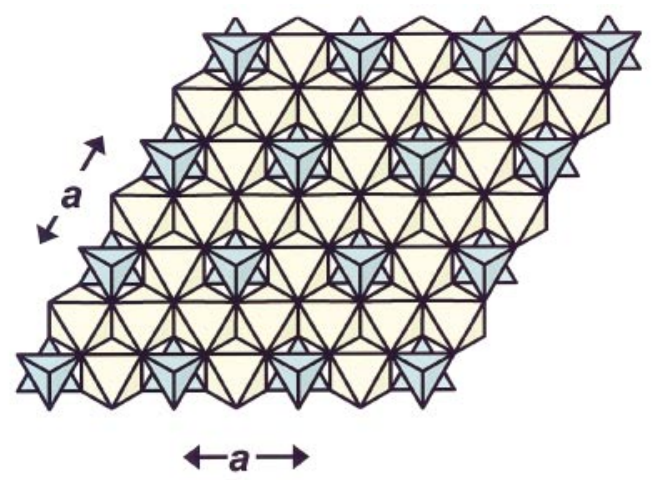

a)
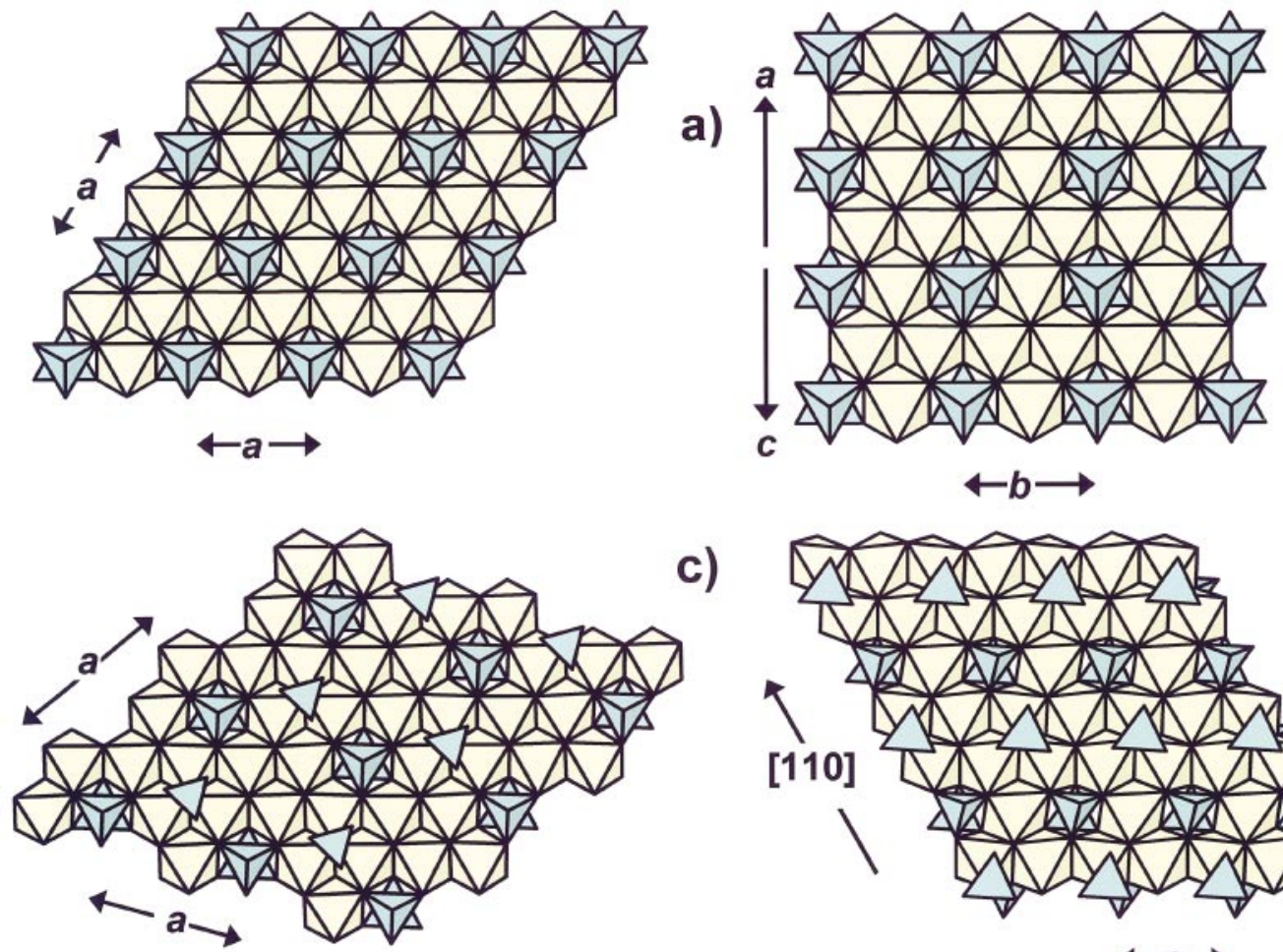

c)
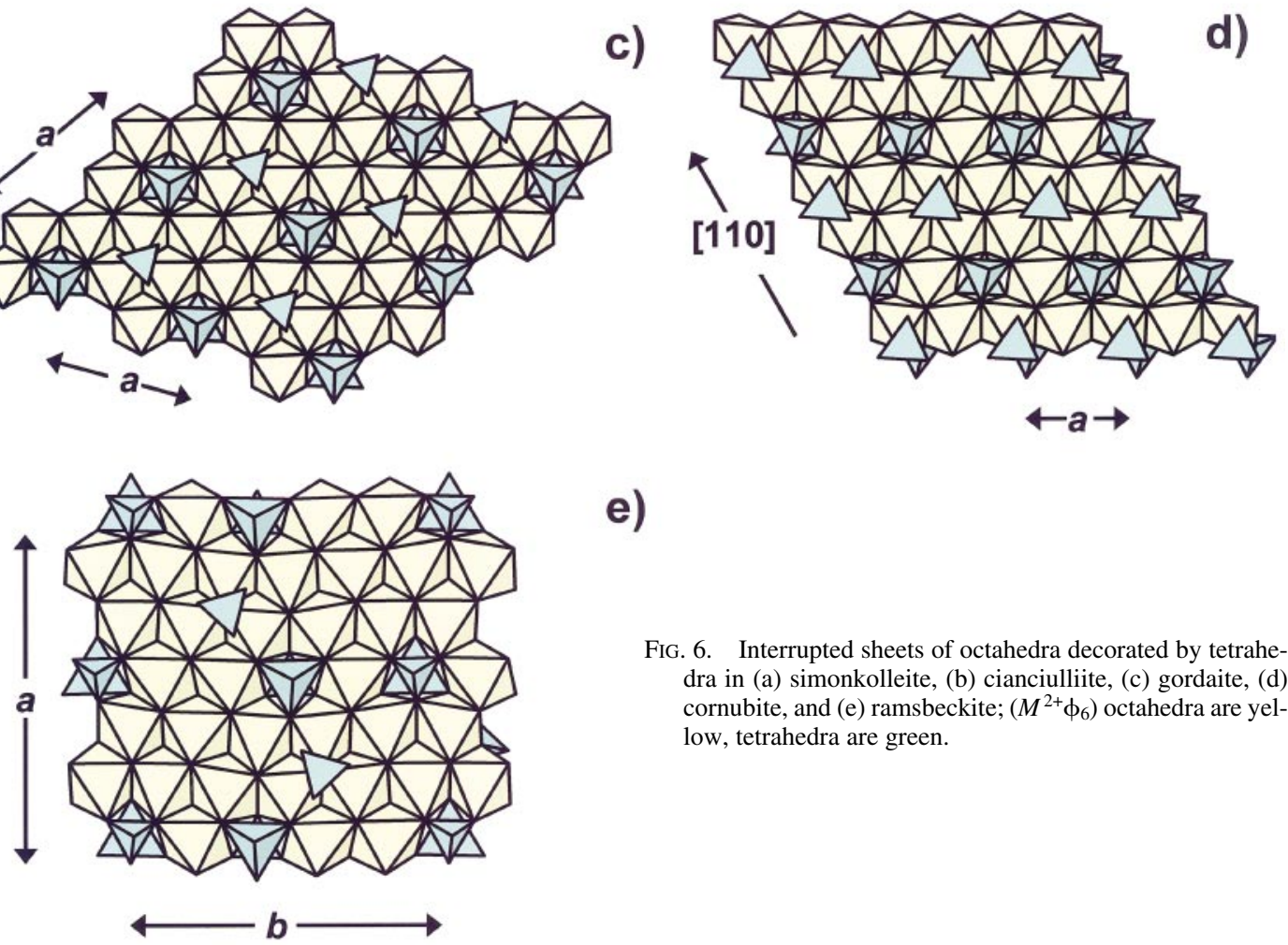

e)

FIG. 6. Interrupted sheets of octahedra decorated by tetrahedra in (a) simonkolleite, (b) cianciulliite, (c) gordaite, (d) cornubite, and (e) ramsbeckite; $\left(M^{2+} \phi_{6}\right)$ octahedra are yellow, tetrahedra are green. 
sheet is occluded by two $\mathrm{Zn}(\mathrm{OH})_{4}$ tetrahedra, each of which are attached to the sheet by three ligands (Fig. $6 b)$, in the same fashion as in simonkolleite. The sheets are held together by hydrogen bonding from $(\mathrm{OH})$ groups of one sheet to $\mathrm{O}$ atoms of adjacent sheets, and to interstitial $\left(\mathrm{H}_{2} \mathrm{O}\right)$ groups.

\section{Gordaite}

Gordaite has vacancies in the sheet of octahedra, and one quarter of the $\mathrm{Zn}$ is tetrahedrally coordinated. In the crystal structure of gordaite, six $\mathrm{Zn}$ cations are octahedrally coordinated, and two $\mathrm{Zn}$ cations are tetrahedrally coordinated. Each $\left\{\mathrm{Zn}(\mathrm{OH})_{4}\right\}$ group links to three sheet anions, and each $\left(\mathrm{SO}_{4}\right)$ tetrahedron links to one sheet anion (Fig. 6c). The sheets are held together by hydrogen bonding from $(\mathrm{OH})$ groups of one sheet to $\mathrm{O}$ atoms of the interstitial [6]-coordinated interstitial $\mathrm{Na}$ atoms.

\section{Bechererite}

In bechererite, there are six octahedrally coordinated $\left(\mathrm{Zn}, \mathrm{Cu}^{2+}\right)$ cations, every seventh octahedron is vacant, and there are two tetrahedrally coordinated $\mathrm{Zn}$ cations. The topology of the $\left({ }^{[6]} M \phi_{2}\right)_{N}$ sheet in becherelite is the same as in gordaite (Fig. 6c), but chemically they are different. In bechererite, there are $\left(\mathrm{SO}_{4}\right)$ tetrahedra on one side and $\left(\mathrm{SiO}_{4}\right)$ tetrahedra on the other side of the sheet. The tetrahedrally coordinated $\mathrm{Zn}$ forms a $\left[T_{2} \mathrm{O}_{7}\right]$ pyro-group in which all non-bridging bonds involve anions of the sheet (i.e., the pyro-group links adjacent sheets into a framework).

\section{Cornubite}

In spite of their identical stoichiometry (Table 7), turanite and cornubite have $\left({ }^{[6]} M \phi_{2}\right)_{N}$ sheets of different topology resulting from different patterns of vacancies within the $\left[\mathrm{Cu} \phi_{2}\right]$ sheet $(\phi=\mathrm{O}, \mathrm{OH})$ (Figs. 4a, 6d). On each side of the vacant octahedron, an (As $\left.\phi_{4}\right)$ tetrahedron is attached to three anions of the sheet and points away from the sheet. The sheets are held together by hydrogen bonding from $(\mathrm{OH})$ groups of one sheet to $\mathrm{O}$ anions of adjacent sheets. The $\left[C u \phi_{2}\right]$ sheets and (As $\left.\phi_{4}\right)$ tetrahedra link together to form a framework similar to that of turanite.

\section{Ramsbeckite}

There is a $\left[\mathrm{Cu} \phi_{2}\right]$ sheet in the crystal structure of ramsbeckite (Fig. 6e), together with two $\mathrm{Zn}$ cations per formula unit in tetrahedral coordination. The $\left(\mathrm{Zn} \phi_{4}\right)$ tetrahedron shares three anions with the sheet and the fourth anion with an $\left(\mathrm{SO}_{4}\right)$ group of an adjacent sheet, forming a framework. There are two types of $\left(\mathrm{SO}_{4}\right)$ groups, and half of them share an $\mathrm{O}$ atom with $\left(\mathrm{Zn} \phi_{4}\right)$ tetrahedra. There is extensive hydrogen bonding between $\left[\mathrm{Cu} \phi_{2}\right]$ sheets involving interstitial $\left(\mathrm{H}_{2} \mathrm{O}\right)$ groups.

\section{SUMMARY}

Turanite, $\mathrm{Cu}^{2+}{ }_{5}\left(\mathrm{~V}^{5+} \mathrm{O}_{4}\right)_{2}(\mathrm{OH})_{4}$, is a framework structure with an interrupted sheet of $\mathrm{Cu}$ octahedra as the structural unit. The crystal structure of turanite is related to the framework structures of cornubite, bechererite and ramsbeckite and the sheet structures of simonkolleite, gordaite and cianciulliite. Its composition is in accordance with the structural refinement, and this work has confirmed the status of turanite as a valid mineral species.

\section{ACKNOWLEDGEMENTS}

Special thanks are due to G.K. Bekenova (Satpaev Geological Institute, Alma-Ata, Kazakhstan), who participated in field work, Mark Cooper, who picked a beautiful crystal out of an aggregation of polysynthetic twins, and N.A. Pekova for a photograph of the holotype specimen of turanite from the Fersman Mineralogical Museum (Moscow, Russia). We also thank Drs. Allan Pring and Phillip G. Slade for their helpful reviews. This work was supported by a Canada Research Chair in Crystallography and Mineralogy and Major Facilities Access, Equipment and Discovery Grants from the Natural Sciences and Engineering Research Council of Canada to FCH.

\section{REFERENCES}

Adiwidjaja, G., Friese, K., Klaska, K.-H. \& Schlüter, J. (1997): The crystal structure of gordaite $\mathrm{NaZn}_{4}\left(\mathrm{SO}_{4}\right)$ $(\mathrm{OH})_{6} \mathrm{Cl} \bullet 6 \mathrm{H}_{2} \mathrm{O}$. Z. Kristallogr. 212, 704-707.

AleXANDRov, S.P. (1923): Tyuya-Muyun radium expedition in 1922. Engineering and Mining Journal-Press 116, 944946.

Brown, I.D. (1981): The bond-valence method: an empirical approach to crystal structure and bonding. In Structure and Bonding in Crystals II (M. O'Keeffe \& A. Navrotsky, eds.). Academic Press, New York, N.Y. (1-30).

BuRNS, P.C. \& HAWTHORNE, F.C. (1995): Coordination-geometry structural pathways in $\mathrm{Cu}^{2+}$ oxysalt minerals. Can . Mineral. 33, 889-905.

$$
\&
$$
(1996): Static and dynamic Jahn-Teller effects in $\mathrm{Cu}^{2+}$-oxysalt minerals. Can. Mineral. 34, 10891105.

CASTOR, S.B. \& FeRdOCK, G.C. (2004): Minerals of Nevada. University of Nevada Press, Reno, Nevada (Nevada Bureau of Mining \& Geology, Spec. Publ. 31).

EFFENBERGER, H. (1988): Ramsbeckite, $(\mathrm{Cu}, \mathrm{Zn})_{15}(\mathrm{OH})_{22}$ $\left(\mathrm{SO}_{4}\right)_{4} \bullet 6 \mathrm{H}_{2} \mathrm{O}$ : revision of the chemical formula based on a structure determination. Neues Jahrb. Mineral., Monatsh., $38-48$. 
FERSMAN, A.E. (1928): On morphology and geochemistry of Tyuya-Muyun. Travaux sur le radium et les minéraux radioactifs 3, 1-92 (in Russ.).

Grice, J.D. \& DunN, P.J. (1991): The crystal structure of cianciulliite, $\mathrm{Mn}(\mathrm{Mg}, \mathrm{Mn})_{2} \mathrm{Zn}_{2}(\mathrm{OH})_{10} \cdot 2-4 \mathrm{H}_{2} \mathrm{O}$. Am. Mineral. 76, 1711-1714.

HAwTHORnE, F.C. \& Schindler, M. (2000): Topological enumeration of decorated $\left[\mathrm{Cu}^{2+} \phi_{2}\right]_{\mathrm{N}}$ sheets in hydroxy-hydrated copper-oxysalt minerals. Can. Mineral. 38, 751-761.

\& Sokolova, E.V. (2002): Simonkolleite, $\mathrm{Zn}_{5}$ $(\mathrm{OH})_{8} \mathrm{Cl}_{2}\left(\mathrm{H}_{2} \mathrm{O}\right)$, a decorated interrupted-sheet structure of the form $\left[\mathrm{M \phi}_{2}\right]_{4}$. Can. Mineral. 40, 939-946.

Hoffmann, C., Armbruster, T. \& Giester, G. (1997): Acentric structure $(\mathrm{P} 3)$ of bechererite, $\mathrm{Zn}_{7} \mathrm{Cu}(\mathrm{OH})_{13}[\mathrm{SiO}$ $(\mathrm{OH})_{3} \mathrm{SO}_{4}$ ]. Am. Mineral. 82, 1014-1018.

INTERNATIONAL TABLES FOR X-RAY CRYSTALlOGRAPHY, vol. C (1992): Kluwer Academic Publishers, Dordrecht, The Netherlands.

KAZANSKY, V.I. (1970): Geological-structural characteristics of Tyuya-Muyun deposit. In Ocherki Geol. Geokhim. Rud. Mestorozhd (F.I. Vol'fson, ed.). Nauka, Moscow, Russia (34-57).

NenAdKeVICH, K.A. (1909): Turanite and alaite - two new vanadium minerals. Proc. Imp. Acad. Sci. St. Petersb. 3, 185187.
Pouchou, J.L. \& Pichoir, F. (1985): "PAP" ( $\rho Z)$ procedure for improved quantitative microanalysis. In Microbeam Analysis - 1985. San Francisco Press, San Francisco, California (104-106).

Pullman, S. \& Thomsson, R. (1999): Nevada mineral locality index. Rocks \& Minerals 74, 370-379.

SHELDRICK, G.M. (1997): SHELX-97: Program for the Solution and Refinement of Crystal Structures. Siemens Energy and Automation, Madison, Wisconsin.

(1998): SADABS User Guide. University of Göttingen, Göttingen, Germany.

Sieber, N.H.W., Hofmeister, W., Tillmanns, E. \& Abraham, K. (1984): Neue Mineraldaten für Kupferphosphate und -arsenate von Reichenbach/Odw. Fortschr. Mineral. 62 , 231-233.

SMOL'YAninOVA, N.N. (1970): Mineralogy and genesis of the Tyuya-Muyun deposit. In Ocherki Geol. Geokhim. Rud. Mestorozhd (F.I. Vol'fson, ed.). Nauka, Moscow, Russia (58-90).

Suloev, A.I. \& Ponomarev, A.L. (1934): On a new discovery of turanite in central Asia. Mineral. Syr'ye 5, 19-22.

Received December 21, 2003, revised manuscript accepted April 8, 2004. 